\title{
Performance of lettuce submitted to the rock dust remineralizer and doses of efficient microorganisms
}

\author{
Westefann dos Santos Sousa ${ }^{1}$, Thiago Souza Campos², Ane Gabriele Vaz Souza², Pedro \\ Henrique Nascimento Cintra ${ }^{3}$, Layanara Oliveira Faria ${ }^{3}$, Talles Eduardo Borges dos Santos ${ }^{3}$
}

\begin{abstract}
${ }^{1}$ Universidade Estadual Paulista "Júlio de Mesquita Filho", Faculdade de Ciências Agronômicas, Campus de Botucatu, São Paulo, Brasil. E-mail: westefannsantos@hotmail.com
\end{abstract}

${ }^{2}$ Universidade Estadual Paulista "Júlio de Mesquita Filho", Faculdade de Ciências Agrárias e Veterinárias, Campus de Jaboticabal, São Paulo, Brasil. E-mail: thiago.s.campos@unesp.br, anevazsouza@gmail.com

${ }^{3}$ Universidade Estadual de Goiás, Unidade Universitária de Ipameri, Goiás, Brasil. E-mail: aphncintra@ gmail.com, layanara.agro@hotmail.com, tallesunesp@yahoo.com.br

Received: 12/09/2020; Accepted: 17/03/2021.

\section{ABSTRACT}

The use of soil remineralizers with efficient microorganisms (EM) can represent an effective and sustainable alternative to improve the growth, development, and yield of cultivated plants. Thus, the present study aimed to evaluate the effect of different doses of EM, in the presence or absence of rock dust (RD), on the development of iceberg lettuce, cultivar Lucy Brown. The design used was completely randomized, arranged in a 2 x 5 factorial scheme, with four replications. The treatments consisted of the presence and absence of RD in the substrate composition, combined with five commercial product doses based on $\operatorname{EM}\left(0,2,4,6\right.$, and $\left.8 \mathrm{~L} \mathrm{ha}^{-1}\right)$. At 30 days after transplanting, root and stem length, head circumference, the number of leaves, stem diameter, leaf area, fresh matter of root, stem, leaf, and shoot, and dry matter of root, stem, leaf, and shoot were evaluated. There was an interaction between the factors for most variables of economic importance. The dose of $4.5 \mathrm{~L} \mathrm{ha}^{-1}$ of the product based on EM, combined with PR, implied the best performance of iceberg lettuce under the studied cultivation conditions.

Keywords: Natural phosphate, Lactuca sativa, Beneficial microorganisms, Vegetable nutrition.

\section{Desempenho da alface submetida ao remineralizador pó de rocha e doses de microrganismos eficientes}

\section{RESUMO}

$\mathrm{O}$ uso de remineralizadores de solo com microrganismos eficientes (EM) pode representar uma alternativa eficaz e sustentável para melhorar o crescimento, desenvolvimento e rendimento produtivo das plantas cultivadas. Assim, o presente trabalho objetivou avaliar o efeito de diferentes doses de EM, na presença ou ausência do pó de rocha (PR), sob o desenvolvimento da alface americana repolhuda cv. Lucy Brown. O delineamento utilizado foi o inteiramente casualizado em esquema fatorial 2 x 5, com quatro repetições. Os tratamentos consistiram na presença e ausência do PR na composição do substrato, combinados com cinco doses do produto comercial a base de EM ( 0 , 2, 4, 6 e $8 \mathrm{~L} \mathrm{ha}^{-1}$ ). Aos 30 dias após o transplantio, avaliou-se o comprimento da raiz e do caule, circunferência da cabeça, número de folhas, diâmetro do caule, área foliar, biomassa fresca radicular, caulinar e foliar, biomassa fresca total da parte aérea, biomassa seca radicular, caulinar e foliar. Houve interação dos fatores para a maioria das variáveis de importância econômica. A dose de 4,5 $\mathrm{L} \mathrm{ha}^{-1}$ do produto a base de EM, combinado ao PR, implicou na melhor performance da cultura, nas condições de cultivo estudadas.

Palavras-chave: Fosfato natural, Lactuca sativa, Microrganismos benéficos, Nutrição de hortaliças. 


\section{Introduction}

The lettuce (Lactuca sativa) belongs to the Asteraceae family, originally from the Mediterranean, and it is grown mainly in temperate regions (Favarato et al., 2017). The crop requires fertile and well-drained soils. This vegetable species globally stands out as the most relevant leafy vegetable, consumed mainly in natura (Celestrino et al., 2017).

The agricultural marketing segments have recently undergone important adaptations due to increasing and versatile consumption, which forces them to practice quantity and quality. Given this, adaptations and technological introductions are necessary, such as the use of inorganic fertilizers in the production of vegetables (Silva, 2009).

This type of inorganic fertilization is common in lettuce crops. However, these are palliative, which temporarily contributes to soil fertility, and improper use can cause long-term environmental damage (Farias et al., 2017). Fertilizer alternatives, such as organic and biological ones, are gaining prominence, as they allow food production with the moderate use of chemical inputs (Carvalho et al., 2018).

In this way, a valid option to increase the yield naturally and minimize the ecological impacts is under the use of efficient microorganisms (EM). These are formed by different groups of yeasts, fungi, and bacteria, which perform various functions in the soil, operating in the degradation and modification of organic material, benefiting the plants nutrition by intensifying the cycling of nutrients (Sousa et al., 2020a). As an example, there are phosphate solubilizing microorganisms, organic acid synthesizers, which solubilize the insoluble phosphates in the rhizosphere (Morocho and Leiva-Mora, 2019), making them readily available to the plant.

Several studies show the positive effect of inducing microorganisms on plants development and the content of some nutrients and chemical compounds (Zlotek and Swieca, 2016). As an example, El-Motty et al. (2010) report an increase in sugars, vitamin $\mathrm{C}$, and some chemical elements $(\mathrm{N}, \mathrm{P}$, and $\mathrm{K})$ production, providing a higher quality of the fruit of Keitt mango trees due to the application of algae and yeast extract. Shehata et al. (2012), when evaluating the response of cucumber plants to leaf application of chitosan and yeasts, observed an increase in plant growth and the concentrations of nutrients in the fruits.

In lettuce, Martins-Filho et al. (2019) ensure that the use of beneficial microorganisms can be a viable alternative to increase crop production through the lower incidence of pathogens and increased absorption of nutrients. The influence on the chemical composition of lettuce, grown under cover due to the application of efficient microorganisms, significantly increased the content of potassium and magnesium in the leaves of the plant (Górski et al., 2017). Other studies also declare that efficient microorganisms are products to be used as a biofertilizer in the cultivation of lettuce, demonstrating positive effects on the soil chemical fertility in the nutrition and cultivation of the crop (Sousa et al., 2020b; Sousa et al., 2020c).

Another agricultural practice used in sustainable agriculture is focused on the use of soil remineralizers, especially rock dust (RD). This product is used to replace soluble fertilizer sources. According to Lopes et al. (2014), the benefits of using crushed rocks in agriculture are numerous due to the gradual release of nutrients from the rocks, which favors the crop throughout its phenology (Martins et al., 2015).

Thus, a promising alternative is the use of efficient microorganisms associated with rock dust, which is an attempt to reduce the use of external inputs and increase the production and maintenance of soil fertility in the short and long term. However, there is no report in the literature on using these products associated with lettuce or the EM solution's ideal dose of EM solution.

Therefore, considering the importance of adopting alternative sources of fertilizers for agriculture and the relevance of using biological products in organic cultivation to potentiate the growth of plants, this study aimed to evaluate the performance of the iceberg lettuce, cultivar Lucy Brown, depending on the composition of the substrate containing rock dust, associated with the application of efficient microorganisms.

\section{Material and Methods}

The research was carried out from November 2019 to January 2020 at the State University of Goiás, Ipameri Unit, Goiás, Brazil. The experiment was installed in a greenhouse covered with transparent plastic and sides closed by a shading screen with a $50 \%$ light radiation interception. The average temperature during the conduction of the experiment in the greenhouse was $24.85{ }^{\circ} \mathrm{C}$. A completely randomized design in a $2 \times 5$ factorial scheme was used, with four replications totaling forty experimental plots. The first factor corresponded to the composition of the substrate (presence and absence of rock dust), and the second factor was composed of doses of the commercial product based on efficient microorganisms $\left(0,2,4,6\right.$, and $\left.8 \mathrm{~L} \mathrm{ha}^{-1}\right)$, having as a proportion, a spray volume of $100 \mathrm{~L} \mathrm{ha}^{-1}$.

The rock dust used, characterized as fine mica schist (FMS), presented in its mineralogical composition $26.2 \%$ albite, $21.4 \%$ biotite, $9.7 \%$ muscovite, $15.8 \%$ chlorite, $19.7 \%$ quartz, $5.7 \%$ garnet, and $1.1 \%$ limonite. The sum of bases $\left(\mathrm{K}_{2} \mathrm{O}+\mathrm{CaO}+\mathrm{MgO}\right)$ was $9.8 \%$, being a source of $\mathrm{Ca}$ and $\mathrm{Mg}$, in addition to micronutrients $(\mathrm{Zn}, \mathrm{Ni}$, and $\mathrm{Cu})$ (Table 1). 
Table 1. Chemical elements present in the samples of fine mica schist (FMS), originated in Pedreira Araguaia, Aparecida de Goiânia, Goiás, Brazil.

\begin{tabular}{|c|c|c|c|c|c|c|c|c|c|}
\hline $\mathrm{SiO}_{2}$ & $\mathrm{Al}_{2} \mathrm{O}_{3}$ & $\mathrm{Fe}_{2} \mathrm{O}_{3}$ & $\mathrm{~K}_{2} \mathrm{O}$ & $\mathrm{Na}_{2} \mathrm{O}$ & $\mathrm{MgO}$ & $\mathrm{CaO}$ & $\mathrm{MnO}$ & $\mathrm{P}_{2} \mathrm{O}_{5}$ & $\mathrm{TiO}_{2}$ \\
\hline 57.7 & 17.1 & 8.9 & 3.2 & 2.3 & 4.8 & 1.8 & 0.1 & 0.2 & 0.9 \\
\hline Co & & & $\mathrm{Cu}$ & Mo & & $\mathrm{Si}$ & $\mathrm{Zn}$ & & B \\
\hline 28.5 & & & 66.6 & 1.5 & & 0.6 & 142 & & 37 \\
\hline
\end{tabular}

$\mathrm{SiO}_{2}=$ silicon dioxide; $\mathrm{Al}_{2} \mathrm{O}_{3}=$ aluminum oxide; $\mathrm{Fe}_{2} \mathrm{O}_{3}=$ iron oxide $; \mathrm{K}_{2} \mathrm{O}=$ potassium oxide $; \mathrm{Na}_{2} \mathrm{O}=$ sodium oxide; $\mathrm{MgO}=$ magnesium oxide $; \mathrm{CaO}=$ calcium oxide $; \mathrm{MnO}=$ manganese oxide; $\mathrm{P}_{2} \mathrm{O}_{5}=$ phosphorus pentoxide; $\mathrm{TiO}_{2}=$ titanium dioxide $;$ Co $=$ cobalt $\mathrm{Ni}=$ nickel $; \mathrm{Cu}=$ copper; $\mathrm{Mo}=$ molybdenum; $\mathrm{Si}=$ silicon; $\mathrm{Zn}=$ zinc, $\mathrm{B}=$ boron

The commercial product based on EM is composed of natural microorganisms without genetic alterations, which coexist in a homogeneous liquid medium containing 95\% water and 5\% sugarcane molasses. The microbiological composition of the product had the following formation: Lactobacillus casei $\left(<4.7 \times 10^{4}\right.$ CFU mL $\left.\mathrm{m}^{-1}\right)$, Lactobacillus acidophilus $\left(>7.9 \times 10^{4} \mathrm{CFU}\right.$ $\left.\mathrm{mL}^{-1}\right)$, and Saccharomyces cerevisiae (>1.5 x $10^{6} \mathrm{CFU}$ $\left.\mathrm{mL}^{-1}\right)$. Before using the product in its concentrated form, it was activated, following the manufacturer's recommendations, in the proportion of $1: 1: 18$, corresponding to the EM product, molasses, and water, respectively.

The seedlings were produced in trays with 200 cells and commercial substrate with coconut fiber and moss peat. For the experiment's installation, polyethylene pots with a capacity of nine liters of soil were used. The substrate was formed by soil and swine organic compost in the proportion of $3: 2$, respectively. The soil and the swine organic compost showed the following physicochemical properties:

Soil: $\mathrm{pH}$ in $\mathrm{CaCl}_{2}=5.2 ; \mathrm{OM}=16 \mathrm{~g} \mathrm{dm}^{-3} ; \mathrm{P}=2.7$ $\mathrm{mg} \mathrm{dm}{ }^{-3} ; \mathrm{K}=0.07$ cmolc $\mathrm{dm}^{-3} ; \mathrm{Ca}=0.8 \mathrm{cmolc} \mathrm{dm}^{-}$ 3; $\mathrm{Mg}=0.4 \mathrm{cmolc} \mathrm{dm}^{-3} ; \mathrm{H}+\mathrm{Al}=1.7 \mathrm{cmolc} \mathrm{dm}^{-3} ; \mathrm{Zn}=$ $1.1 \mathrm{mg} \mathrm{dm}^{-3}$ and the following structural composition: clay $=310 \mathrm{~g} \mathrm{~kg}^{-3}$; silt $=80 \mathrm{~g} \mathrm{~kg}^{-1}$ e sand $=610 \mathrm{~g} \mathrm{~kg}^{-1}$.

Organic compost: $\mathrm{OM}=93.47 \%$; Ash $=6.54 \%$; Ratio $\mathrm{C} / \mathrm{N}=36.50 ; \mathrm{pH}$ in $\mathrm{CaCl}_{2}=5.70 ; \mathrm{N}=1.47 \% ; \mathrm{P}=$ $0.31 \% ; \mathrm{K}=2.18 \% ; \mathrm{Ca}=0.23 \% ; \mathrm{Mg}=0.07 \% ; \mathrm{S}=$ $0.27 \% ; \mathrm{Fe}=260 \mathrm{mg} \mathrm{kg}^{-1} ; \mathrm{Mn}=81 \mathrm{mg} \mathrm{kg}^{-1} ; \mathrm{Cu}=11 \mathrm{mg}$ $\mathrm{kg}^{-1} ; \mathrm{Zn}=47 \mathrm{mg} \mathrm{kg}^{-1} ; \mathrm{B}=43 \mathrm{mg} \mathrm{kg}^{-1}$.

The plants were transplanted to the pots 15 days after sowing (DAS), where each experimental unit (pot) received three plants, and after five days, thinning was carried out, with one plant per pot. The amount of rock dust incorporated in the substrate was defined according to the recommended in scientific studies for lettuce, being used the corresponding to $2,000 \mathrm{~kg} \mathrm{ha}^{-1}$ (Groth et al., 2017). The application of the efficient microorganism's doses occurred in two periods, commonly to all the treatments that received the application, being the first in the transplant of the seedlings and the second 15 days after the transplant (DAT).
The evaluations were performed at 30 DAT, collecting all parts of the plants. The material was sent to the interdisciplinary laboratory of the State University of Goiás - Ipameri unit and the following agronomic indicators were evaluated: root and stem length, measured with the aid of a millimeter ruler; circumference of the head, placing a measuring tape on the widest part of the head of the lettuce; the number of leaves, counting all commercially viable leaves; stem diameter, measured with the aid of a caliper; and leaf area, photographing the healthy leaves of each treatment, and then the images were processed in the ImageJ software to measure the leaf area (NIH, 2011).

The measurements of fresh and dry matter variables (maintained in a forced air circulation oven at $70{ }^{\circ} \mathrm{C}$ for 48 hours) were performed using a precision scale. Fresh matter of root, stem, and leaf was evaluated. The shoot fresh matter was obtained by the sum between leaf and stem fresh matter. Finally, the dehydrated material was weighed to determine root, stem, leaf, and shoot dry matter.

The results were subjected to analysis of variance by the F-test. The means obtained from the substrate composition in the presence and absence of rock dust were compared by the Tukey test at the level of 5\% probability. The means from the doses of efficient microorganisms were submitted to regression analysis. Statistical analyses and plotting of the graphics were performed with the aid of the software R 3.4 (R Core Team, 2017) and SigmaPlot 10.0 (Systat Software, 2006).

\section{Results and Discussion}

The substrate composition (SC), with the presence or absence of RD, showed the effect of significant interaction with the doses of efficient microorganisms (EM) on the characteristics of root length, head circumference, and leaf area (Table 2). Regarding the variables presented in Table 3 , there was a significant interaction of the studied factors (SC x EM) for the fresh matter of root, leaf, and total, and dry matter of root and leaf. The other variables evaluated in the present study 
did not present significant results for the interaction of the factors nor significant effects for the isolated factors. An exception was observed for stem fresh matter (SFM), which showed a significant result for the substrate composition. This variable had $14.71 \mathrm{~g}$ when rock dust was used in the substrate composition, while in the absence of RD, the result was $12.37 \mathrm{~g}$ (Table 3). This greater increase in SFM can be justified by the greater supply of nutrients in the substrate composition provided by rock dust (Freitas et al., 2013).

The regression analysis data from the interaction between the factors tested for root length, head circumference, leaf area, and shoot fresh matter are shown in Figure 1. The best fit curve for all variables was the polynomial quadratic, indicating that there is a maximum effect dose. The coefficient of determination values $\left(\mathrm{R}^{2}\right)$ ranged between $79 \%$ and $99 \%$, showing an adequate and precise regression model adjustment.

The root length, leaf area, and shoot fresh matter of lettuce were favored in the presence of the RD, obtaining, respectively, maximum increments of $17.91 \mathrm{~cm}, 185.33$ $\mathrm{cm}^{2}$, and $144.13 \mathrm{~g}$ plant $^{-1}$ (Figure 1A, 1C and 1D) in the respective doses equivalent to $5.6 ; 5.4$ and $3.8 \mathrm{~L} \mathrm{ha}^{-1}$ of EM. The maximum head circumference $(50.33 \mathrm{~cm})$ was obtained at a dose of $5.14 \mathrm{~L} \mathrm{ha}^{-1}$ of EM, without the RD incorporation (Figure 1B).

Gonzáles et al. (2019) obtained results similar to the present study using efficient microorganisms, with a significant effect on the head circumference, number of leaves, and leaves in commercial pattern with the lowest dose used $\left(8 \mathrm{~mL} \mathrm{~m}^{-2}\right)$. The lettuce leaf area is an important factor because it is the part to be marketed and consumed in leafy vegetables. Diamante et al. (2013) highlight that the consumer observes the appearance and the leaf volume to later purchase the vegetable in question.

For the fresh and dry matter of root and leaf, the best fit was the quadratic model (Figure 2).

Table 2. Analysis of variance and test of means for the growth characteristics of iceberg lettuce, cultivar, Lucy Brown, depending on the substrate composition (SC) with the presence and absence of rock dust (RD) and doses of efficient microorganisms (EM).

\begin{tabular}{|c|c|c|c|c|c|c|}
\hline \multirow[t]{3}{*}{ Variation source } & \multicolumn{6}{|c|}{ Medium Squares } \\
\hline & RL & SL & $\mathrm{HC}$ & \multirow{2}{*}{$\begin{array}{l}\mathrm{NL} \\
--- \text { uni --- }\end{array}$} & SD & \multirow{2}{*}{$\begin{array}{l}\mathrm{LA} \\
---\mathrm{cm}^{2}--\end{array}$} \\
\hline & \multicolumn{3}{|c|}{------------------- cm ------------------ } & & --- mm --- & \\
\hline $\mathrm{SC}$ & $126.02^{* * *}$ & $0.2250^{\mathrm{ns}}$ & $146.26^{* * *}$ & $0.6250^{\mathrm{ns}}$ & $0.4000^{\mathrm{ns}}$ & $2868.5^{* *}$ \\
\hline EM & $13.212^{* *}$ & $0.2125^{\mathrm{ns}}$ & $85.907^{* *}$ & $2.7875^{\mathrm{ns}}$ & $1.0875^{\mathrm{ns}}$ & $4417.4^{* *}$ \\
\hline SC $x$ EM & $14.712^{* * *}$ & $0.2875^{\mathrm{ns}}$ & $129.97^{* *}$ & $4.1875^{\mathrm{ns}}$ & $2.9625^{\mathrm{ns}}$ & $3468.4^{* *}$ \\
\hline $\mathrm{CV}(\%)$ & 8.36 & 15.30 & 4.46 & 11.80 & 15.21 & 1.63 \\
\hline Treatments & \multicolumn{6}{|l|}{ Averages } \\
\hline With RD & $15.80 \mathrm{a}$ & $4.67 \mathrm{a}$ & $43.29 \mathrm{~b}$ & $17.30 \mathrm{a}$ & $8.30 \mathrm{a}$ & $150.21 \mathrm{~b}$ \\
\hline Without RD & $12.25 \mathrm{~b}$ & $4.52 \mathrm{a}$ & $47.11 \mathrm{a}$ & $17.05 \mathrm{a}$ & $8.50 \mathrm{a}$ & $167.15 \mathrm{a}$ \\
\hline $\operatorname{SMD}(5 \%)$ & 0.757 & 0.454 & 1.303 & 1.309 & 0.825 & 1.677 \\
\hline
\end{tabular}

$\mathrm{RL}=$ root length, $\mathrm{SL}=$ stem length, $\mathrm{HC}=$ head circumference, $\mathrm{NL}=$ number of leaves, $\mathrm{SD}=$ stem diameter, and LA $=$ leaf area. $\mathrm{Ns}$ $=$ not significant, $*$ and $* *=$ significant by the F-test at $5 \%$ and $1 \%$ probability, respectively. Means followed by the same letter in the columns are statistically equal by the Tukey test at $5 \%$ probability. SMD $=$ significant minimum difference.

Table 3. Analysis of variance and test of means for the fresh and dry matter characteristics of iceberg lettuce, cultivar Lucy Brown, depending on the substrate composition (SC) with the presence and absence of rock dust (RD) and doses of efficient microorganisms (EM).

\begin{tabular}{|c|c|c|c|c|c|c|c|}
\hline \multirow[t]{2}{*}{ Variation source } & \multicolumn{7}{|c|}{ Medium Squares } \\
\hline & RFM & SFM & LFM & SHFM & RDM & SDM & LDB \\
\hline $\mathrm{SC}$ & $8.454^{\mathrm{ns}}$ & $54.54^{* * *}$ & $60.49^{\text {* }}$ & $229.92^{* *}$ & $0.001^{\mathrm{ns}}$ & $0.043^{\mathrm{ns}}$ & $1.152 \mathrm{~ns}$ \\
\hline EM & $2.929^{\mathrm{ns}}$ & $38.37^{\mathrm{ns}}$ & $818.1^{* *}$ & $870.47^{* *}$ & $0.013^{\mathrm{ns}}$ & $0.004^{\mathrm{ns}}$ & $0.540^{\mathrm{ns}}$ \\
\hline $\mathrm{SC} \times \mathrm{EM}$ & $8.2872 *$ & $44.15^{\mathrm{ns}}$ & $216.5^{* *}$ & $2443.3^{* *}$ & $0.119^{* *}$ & $0.011^{\mathrm{ns}}$ & $1.724^{* * *}$ \\
\hline $\mathrm{CV}(\%)$ & 16.23 & 13.40 & 2.14 & 2.13 & 21.39 & 34.18 & 22.88 \\
\hline Treatments & \multicolumn{7}{|c|}{ Averages } \\
\hline With RD & $10.20 \mathrm{a}$ & $14.71 \mathrm{a}$ & $116.45 \mathrm{a}$ & $131.17 \mathrm{a}$ & $0.617 \mathrm{a}$ & $0.352 \mathrm{a}$ & $2.545 \mathrm{a}$ \\
\hline Without RD & $9.28 \mathrm{a}$ & $12.37 \mathrm{~b}$ & $114.00 \mathrm{~b}$ & $126.37 \mathrm{~b}$ & $0.605 \mathrm{a}$ & $0.286 \mathrm{a}$ & $2.885 \mathrm{a}$ \\
\hline SMD (5\%) & 1.021 & 1.172 & 1.593 & 1.771 & 0.084 & 0.070 & 0.401 \\
\hline
\end{tabular}

RFM = root fresh matter, SFM = stem fresh matter, LFM = leaf fresh matter, SHFM = shoot fresh matter, RDM = root dry matter, $\mathrm{SDM}=$ stem dry matter, and LDB $=$ leaf dry matter. $\mathrm{ns}=$ not significant, $*$ and $* *=$ significant by the $\mathrm{F}$-test at $5 \%$ and $1 \%$ probability, respectively. Means followed by the same letter in the columns are statistically equal by the Tukey test at $5 \%$ probability. $\mathrm{SMD}=$ significant minimum difference. 

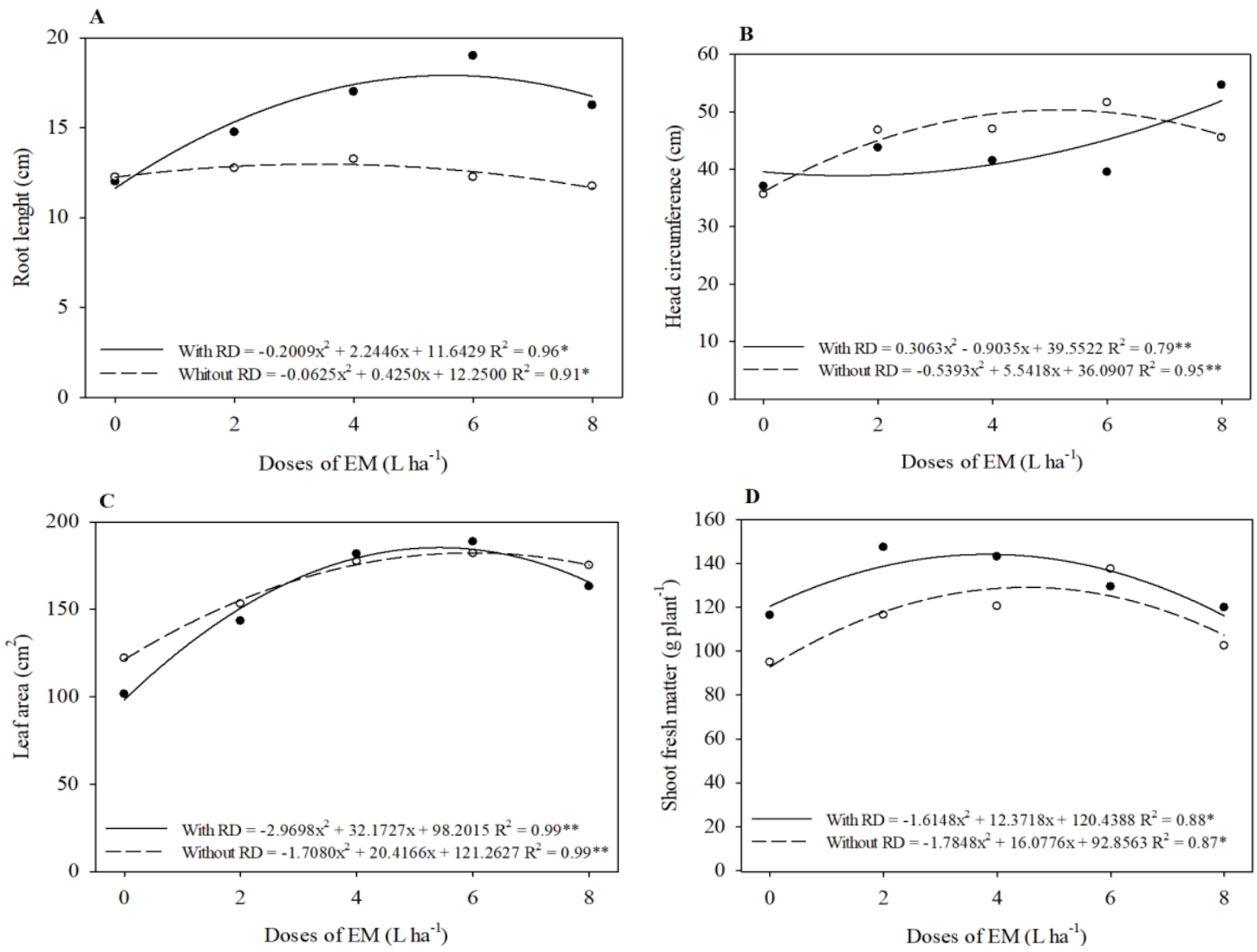

Figure 1. Regression analysis for the variables root length (A), head circumference (B), leaf area (C), and shoot fresh matter (D) of iceberg lettuce, cultivar Lucy Brown, depending on the substrate composition (SC) with the presence and absence of rock dust (RD) and doses of efficient microorganisms (EM).
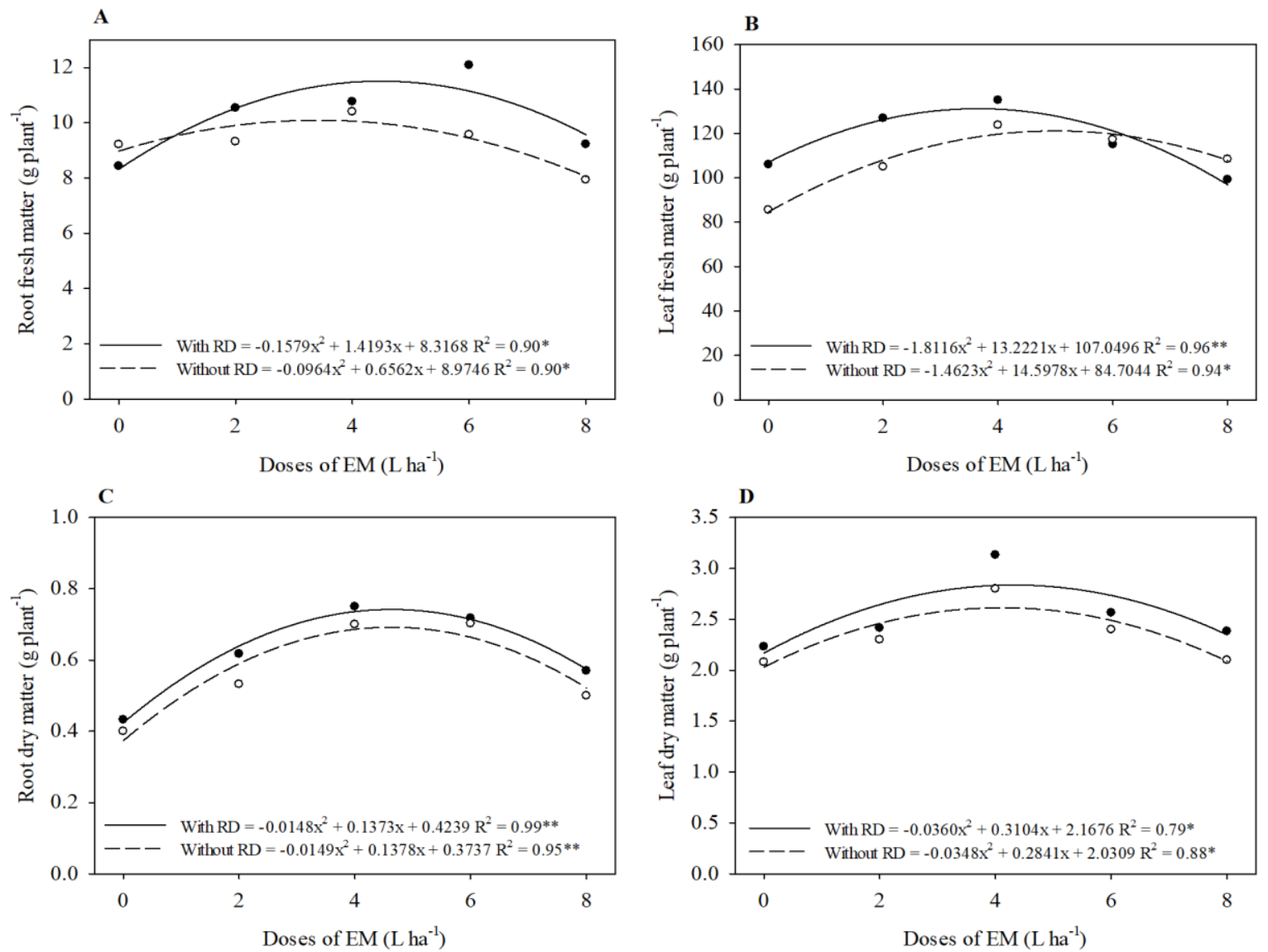

Figure 2. Regression analysis for root fresh matter (A), leaf fresh matter (B), root dry matter (C), and leaf dry matter (D) of iceberg lettuce, cultivar Lucy Brown, depending on the substrate composition (SC) with the presence and absence of rock dust (RD) and doses of efficient microorganisms (EM). 
It is worth mentioning that when the root length was observed, the greatest results were observed in the treatments with doses of EM in the presence of RD when compared with the absence of $\mathrm{RD}$ in the composition of the substrate. This result may be related to a possible increase in micronutrient availability in the substrate with RD presence, such as zinc (Table 1), causing an increase in plant root system development (Welter et al., 2011).

The determination coefficient $\left(\mathrm{R}^{2}\right)$ showed a high adjustment of the regression models, with values ranging between $79 \%$ and $99 \%$. The presence of $\mathrm{RD}$ in the composition of the substrate, associated with the EM doses increased the biomass of the lettuce, with the doses of 4.5 and $3.6 \mathrm{~L} \mathrm{ha}^{-1}$, being those that showed the greatest positive effects, respectively, for the fresh matter of root $\left(11.51 \mathrm{~g} \mathrm{plant}^{-1}\right)$ and leaf (131.17 g plant $^{-1}$ ) (Figure 2A and 2B), and 4.6 and 4.3 $\mathrm{L} \mathrm{ha}^{-1}$ for the dry matter of root $\left(0.742 \mathrm{~g} \mathrm{plant}^{-1}\right)$ and leaf $\left(2.84 \mathrm{~g} \mathrm{plant}^{-1}\right)$, respectively (Figure 2C and 2D).

Prihandarini and Murni (2018) found no significant effect on leaf area, total fresh and dry matter when using inorganic fertilizers and coconut wastewater fertilizers fertilized with efficient microorganisms (Lactobacillus bulgaricus, Lactobacillus acidophilus, and Streptococcus thermophiles). However, in the present study, it was possible to verify that these efficient microorganisms positively affect the biomass characteristics, especially when using the RD remineralizer.

This result is in line with that reported by Groth et al. (2017), who, when incorporating basalt dust in the soil, observed a significant increase in the variables of root growth and dry weight of lettuce. Alovisi et al. (2017) also state that basalt dust can be considered an alternative source of complementary fertilizer in plant nutrition. Thus, the RD presents a potential source for complementing the lettuce nutrition, which, coupled with efficient microorganisms, may have met the crop nutritional needs, explaining the greater increase in fresh and dry matter of the plants demonstrated in the present work.

The absence of rock dust associated with EM doses also showed variations, with a dose of maximum effect. However, the results for the mentioned variables were superior when the RD was present in the substrate composition. It is possible to assume that the proportions of nutrients readily available to plants at an early stage of development were lower for treatments with the presence of RD. Because it is a slow-release compound, the initial stage of substrate degradation by the soil microfauna can be characterized by a temporary immobilization of nutrients by microorganisms since they aim to maintain their metabolism for later release (Cardoso and Andreote, 2016).

The use of RD in the cultivation of vegetables depends on processes related to the soil's biological activity since the solubilization of the material requires in large part the action of many organisms. The availability of nutrients contained in rocks is mediated by the action and interaction of organisms with the environment. Thus, the introduction of EM in the soil will provide greater microbial activity in the system, which may favor the release of nutrients from the RD (Morocho and Leiva-Mora, 2019).

In absolute terms, it is noted that there is a relationship between the factors studied, wherein the presence of RD with the addition of EM, satisfactory results of variables of commercial importance were obtained. Given the results, the simultaneous use of the remineralizer with EM shows potential in crop production since the efficient microorganisms assist in the process of decomposition and disposal of organic substrates and can also produce enzymes, beneficial hormones and reduce the incidence of pathogens, a fact reflected in the quality and yield of the crops.

\section{Conclusions}

The results indicate that both the rock dust remineralizer and the efficient microorganisms, applied in isolation or associated, represent an alternative to increasing yield and sustainability in the production systems of Lactuca sativa.

In absolute terms, an approximate dose equivalent to $4.5 \mathrm{~L} \mathrm{ha}^{-1}$ of the product based on efficient microorganisms is recommended, associated with rock dust $\left(2,000 \mathrm{~kg} \mathrm{ha}^{-1}\right)$, showing a greater positive effect on the crop's agronomic characteristics under the studied organic cultivation conditions.

\section{Authors' Contribution}

Westefann dos Santos Sousa, Thiago Souza Campos, Ane Gabriele Vaz Souza, Pedro Henrique Nascimento Cintra, Layanara Oliveira Faria and Talles Eduardo Borges dos Santos actively contributed to the installation and conduct of the experiment, as well as data analysis and writing of the article.

\section{Acknowledgments}

The Agronomists Cid Simões and Rogério Aoyagui, representatives of Technology $E M{ }^{\circledR}$ in Brazil (AMBIEM Ltda.), for all the support given during the conduct of this work. 


\section{Bibliographic References}

Alovisi, A.M.T., Taques, M.M., Alovisi, A.A., Tokura, L.K., Silva, R.S., Piesanti, G.H.L.M., 2017. Alterações nos atributos químicos do solo com aplicação de pó de basalto. Acta Iguazu, 6 (5), 69-79. DOI: https://doi.org/10.48075/actaiguaz.v6i5.18471.

Cardoso, E.J.B.N., Andreote, F.D., 2016. Microbiologia do solo. Piracicaba: ESALQ. DOI: https://doi.org/10.11606/9788586481567.

Carvalho, P.A.D., Barros, V.M.D.S., Figueiredo, N.O., Barros, M.V.D.S., Ferreira, F.M.C., 2018. Desempenho agronômico de rúcula (Eruca sativa) em função do uso de microrganismos eficientes (EM) e de palhada. Cadernos de Agroecologia, 13 (1), 1-7. http://cadernos.abaagroecologia.org.br/index.php/cadernos/article/view/1263. (accessed March 17, 2021).

Celestrino, R.B., Almeida, J.A.D., Silva, J.P.T.D., Luppi, V.A.D.S., Vieira, S.C., 2017. Novos olhares para a produção sustentável na agricultura familiar: avaliação da alface americana cultivada com diferentes tipos de adubações. Revista Eletrônica Competências Digitais para Agricultura $\begin{array}{llll}\text { Familiar, } & 3 & \text { (1), } & \text { 66-87. }\end{array}$ https://owl.tupa.unesp.br/recodaf/index.php/recodaf/article/vie w/43 (accessed March 17, 2021).

Diamante, M.S., Seabra Junior, S., Inagaki, A.M., Silva, M.B., Dallacort, R., 2013. Produção e resistência ao pendoamento de alfaces tipo lisa cultivadas sob diferentes ambientes. Revista Ciência Agronômica, 44 (1), 133-140. DOI: https://doi.org/10.1590/S1806-66902013000100017.

El-Motty, E.Z.A., Shahin, M.F.M., El-Shiekh, M.H., El-AbdMigeed, M.M.M., 2010. Effect of algae extract and yeast application on growth, nutritional status, yield and fruit quality of Keitte mango trees. Agriculture and Biology Journal of North America, 1 (3), 421-429.

Farias, D.B.D.S., Lucas, A.A.T., Moreira, M.A., Nascimento, L.F.D.A., Filho, J.C.F.D.S., 2017. Cobertura do solo e adubação orgânica na produção de alface. Revista Ciências

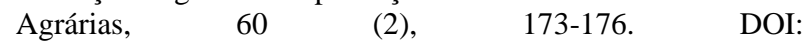
http://dx.doi.org/10.4322/rca.2493.

Favarato, L.F., Guarçoni, R.C., Siqueira, A.P., 2017. Produção de alface de primavera/verão sob diferentes sistemas de cultivo. Revista Científica Intelletto, 2 (1), 16-28. https://biblioteca.incaper.es.gov.br/digital/handle/item/2817 (accessed March 17, 2021).

Freitas, G.A., Silva, R.R., Barros, H.B., Vaz-de-Melo, A., Abrahão, A.P., 2013. Produção de mudas de alface em função de diferentes combinações de substratos. Revista Ciência

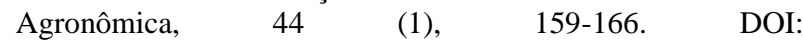
http://dx.doi.org/10.1590/S1806-66902013000100020.

Gonzáles, R.L., Ramos, J.P., Hernández, Y.P., Espinosa, I.P., Jiménez, S.L.R., Alonso, D.P., 2019. Improvement of the agricultural productivity of lettuce and radish by using efficient microorganisms. Revista Facultad Nacional de Agronomía Medellín, 72 (3), 8937-8943. DOI: http://dx.doi.org/10.15446/rfnam.v72n3.76967.

Górski, R., Kleiber, T., Sobieralski, K., 2017. The influence of effective microorganisms application on the chemical composition in lettuce grown under cover. Ecological Chemistry and Engineering, 24 (1), 113-121. DOI: http://dx.doi.org/10.2428/ecea.2017.24(1)9.

Groth, M.Z., Bellé, C., Bernardi, D., Borges Filho, R.C., 2017. Pó-de-basalto no desenvolvimento de plantas de alface e na dinâmica populacional de insetos. Revista de Ciências $\begin{array}{llll}\text { Agroveterinárias, } & 16 & \text { (4), 433-440. } & \text { DOI: }\end{array}$ https://doi.org/10.5965/223811711642017433.

Lopes, O.M.M., Carrilho, E.N.V.M., Lopes-Assad, M.L.R.C., 2014. Effect of rock powder and vinasse on two types of soils. Revista Brasileira de Ciência do Solo, 38 (5): 1547-1557. DOI: http://dx.doi.org/10.1590/S0100-06832014000500020.

Martins, V., Silva, D.R.G., Marchi, G., Leite, M.C.A., Martins, É.D.S., Gonçalves, A.S.F., Guilherme, L.R.G., 2015. Effect of alternative multinutrient sources on soil chemical properties. Revista Brasileira de Ciência do Solo, 39 (1), 194 204. DOI: http://dx.doi.org/10.1590/01000683rbcs20150587.

Martins-Filho, A.P., Medeiros, E.V., Barbosa, J.G., Barbosa, J.M.P., Kuklinsky-Sobral, J., Souza-Motta, C., 2019. Combined effect of Pseudomonas sp. and Trichoderma aureoviride on lettuce growth promotion. Bioscience Journal, 35 (2), 419-430. DOI: https://doi.org/10.14393/BJv35n2a20198-41892.

Morocho, M.T., Leiva-Mora, M., 2019. Microorganismos eficientes, propiedades funcionales y aplicaciones agrícolas.

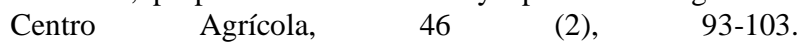
http://scielo.sld.cu/scielo.php?script=sci_arttext\&pid=S025357852019000200093 (accessed March 17, 2021).

NIH. NATIONAL INSTITUTES OF HEALTH. 2011. Image Processing and Analysis in Java. https://imagej.nih.gov/ij/ (accessed March 17, 2021).

Prihandarini, R., Murni, E., 2018. Innovation of microorganism technology and utilization of waste of coconut water for Spur growth of Lettuce (Lactuca sativa $\mathrm{L}$ ). Journal of Applied and Physical Sciences, 4 (1), 1-7. DOI: https://doi.org/10.20474/japs-4.1.1.

R Core Team. 2017. R: A language and environmental for statistical computing. Vienna, Austria. Disponível em: http://www.R-project.org (accessed March 17, 2021).

Shehata, S.A., Fawzy, Z.F., El-Ramady, H.R., 2012. Response of cucumber plants to foliar application of chitosan and yeast under greenhouse conditions. Australian Journal of Basic and $\begin{array}{llll}\text { Applied } & \text { Sciences, } & 4 & \text { (4), }\end{array}$ https://www.cabdirect.org/cabdirect/abstract/20123314480 (accessed March 17, 2021).

Silva, E.C., 2009. Anita: cultivar de alface de verão para cultivo protegido no solo e em hidroponia. Horticultura Brasileira, $27 \quad$ (2), 260-262. DOI: https://doi.org/10.1590/S0102-05362009000200025.

Sousa, W.S., Souza, A.G.V., Campos, T.S., Cintra, P.H.N., Faria, L.O., Melo, O.F.P., 2020a. Germinação e sanidade de sementes de trigo em função da inoculação com microrganismos eficientes. Acta Iguazu, 9(3), 9-19. DOI: https://doi.org/10.48075/actaiguaz.v9i3.23979.

Sousa, W.S., Pontes, J.R.V., Melo, O.F.P., 2020b. Effect of biofertilizer on soil fertility and lettuce nutrition. Revista 
Agrogeoambiental, $\quad 12 \quad$ (1), 26-39. DOI: http://dx.doi.org/10.18406/2316-1817v12n120201414.

Sousa, W.S., Pontes, J.R.V., Melo, O.F.P., 2020c. Efficient Microorganisms in lettuce cultivation. Revista Agrogeoambiental, $\quad 12 \quad$ (2), 9-17. DOI: http://dx.doi.org/10.18406/2316-1817v12n220201456.

Systat Software. 2006. Inc. For windows, version 10.0. SigmaPlot, Chicago, Ilinois.

Welter, M.K., Melo, V.F., Bruckner, C.H., Góes, H.T.P., Chagas, E.A., Uchôa, S.C.P., 2011. Efeito da aplicação de pó de bolsato no desenvolvimento inicial de mudas de camucamu (Myrciaria dubia). Revista Brasileira de Fruticultura, 33 (3), 922-931. DOI: https://doi.org/10.1590/S010029452011000300028.

Zlotek, U., Swieca, M., 2016. Elicitation effect of Saccharomyces cerevisiae yeast extract on main healthpromoting compounds and antioxidant and anti-inflammatory potential of butter lettuce (Lactuca sativa L.). Journal of the Science of Food and Agriculture, 96 (7), 2565-2572. DOI: https://doi.org/10.1002/jsfa.7377. 